\title{
Anthropocene East Anglia
}

Accepted for The Sociological Review

Richard D.G. Irvine

Division of Social Anthropology, University of Cambridge, UK

\begin{abstract}
As we find ourselves in a geological epoch of our own making, it becomes necessary to reconsider the temporal scale of ethnographic enquiry; the effect of human behaviour is shown as a mark in deep time. Focussing on the East Anglian fenland, UK, this paper considers the importance of thinking about long-term environmental change for the understanding of human life. First, I explore the way in which human geological agency has transformed the landscape. I then go on to argue that while the scale of such changes can only be understood against the backdrop of geological time, social life in the region nevertheless demonstrates "temporal lock-in", which I define as an increasing fixation with the landscape of a single point in history. The consequence of such temporal lock-in is that long term environmental variability becomes, literally, unthinkable; yet surface-level certainties of the present are called into question when the timescale of deep history is brought into view.
\end{abstract}

Keywords

Anthropocene, temporality, landscape, environment, geology 


\section{Anthropocene East Anglia}

\section{Social geomorphology}

Life below sea level: drainage ditches cutting across the land, pumping stations fighting inundation, water carried above the fields behind raised clay banks. Such land raises topographical and sociological questions. What factors shaped the low lying landscape, and to what extent have those who live and work there adapted to the risks and possibilities of such terrain? This article is about the flat, low-lying fenlands of East Anglia. This is productive land. 88\% of the region's 1,500 square miles are under cultivation, and most of this area is classified as Grade 1 - the highest possible grade - under the Department for Environment, Food, and Rural Affairs' Agricultural Land Classification. This designates:

Land with no or very minor limitations to agricultural use. A very wide range of agricultural and horticultural crops can be grown and commonly includes top fruit, soft fruit, salad crops and winter harvested vegetables. Yields are high and less variable than on land of lower quality.

Assessed in this way, the agricultural utility of the region is clear: half of the total Grade 1 farmland in England is in the East Anglian fens. This push for agricultural utility within the fenland has also led to what has been described as a great ecological disaster - destruction of peat wetland habitat on a near-total scale.

The fenland formed under conditions of rising sea levels and subsequent estuarine backup and incursion over the period of the early to mid-Holocene; the shifting of the boundary between land and water between 6000 and 3000BC, with what had been dry-land become an extensive wetland, led to significant deposition of silt around the coast, and the formation of peat under waterlogged conditions further inland (Godwin, 1978; Evans and Hodder, 2006a, 2006b). This underlying soil, the product of a changing climate following the last glacial maximum, is what makes the land so prized for agriculture. The subsequent transformation of this wetland to farmland, 
in order to take advantage of the richness created by these historic inundations, has transformed its character once again. This is indeed a "physical geography as modified by human action" (Marsh, 1864).

The recognition that human history and geological processes are intertwined has gained particular significance in the wake of claims that we find ourselves in the Anthropocene - a geological epoch of our own making. The coinage of this term by atmospheric chemist Paul Crutzen and biologist Eugene Stoermer (Crutzen and Stoermer, 2000) has highlighted how important it is to explain the role of humans in driving geologic, atmospheric and geomorphological changes. The coinage is a lexical analogy with the construction of other recent geological epochs, such as the Holocene, the epoch we are commonly assumed to be within which is taken to start around 12,000 years ago following the last glacial period, pushing us to take seriously the idea that the transformations we have caused as a species have had such a significant effect that we need to think of our role as triggering a new geological phase distinct from the last. In August 2016 a working group of the Subcommission on Quaternary Stratigraphy announced that they would formally recommend the inclusion of the 'Anthropocene' epoch within the International Chronostratigraphic Chart, more commonly known as the Geological Time Scale. The search continues for the most appropriate stratigraphic marker indicating the presence of the Anthropocene in the geological record. Yet already, the concept of the Anthropocene has been an important provocation for the study of human-environment relations, drawing attention to the material impacts and material conditions of human existence on a planetary level.

Pálsson et al. (2013, p.6) have argued that the concept of the Anthropocene calls attention to the limits and boundaries of human behaviour. Further to this, they suggest that such a recognition, by necessity, requires a move beyond dualisms of nature and society, and that in turn this requires a reconfiguration of the relationship between the natural and social sciences. As Chakrabarty (2009, p.212) has argued, "the wall between human and natural sciences has been breached", and as such, we need to read global histories of capital in conjunction with the history of resource extraction and 
the ever-expanding use of fossil fuels (2009, p.212). In the context of an Anthropology of Britain, it is necessary to pay close attention to these carbon histories (Mitchell, 2011) - especially given the initial suggestion by Crutzen and Stoermer (2000) that the Anthropocene emerges following the invention of the steam engine and the associated increase in global concentrations of carbon dioxide and methane; a pivotal moment in the social and economic history of Britain as well as the history of earth's atmosphere - and as Mitchell attempts to show, the history of democracy and of the modern state is entangled with the extraction of coal and of oil. In this paper, what I set out to provide is a particular carbon history: a history of the drainage of peat wetland and the consequent oxidation of carbon (known as 'wastage') as the rich organic soil is exposed.

This kind of anthropological perspective engages us with what Ulrich Beck (2010, p.176) has described as an "ecological subtext" in Max Weber's Protestant Work Ethic and the Spirit of Capitalism, embodied in his remark that the conditions of machine production will perhaps determine the lives of individuals "until the last ton of fossilized coal is burnt" (Weber 1930, p.181) - that is, until capitalism consumes its own material conditions (Beck 2010, pp.176-177). Here we see the interaction of idealism and materialism that exemplifies Weber's work; a recognition not only of the ethical motivations that shape labour (and thus land), but also of the geological grounding that delimits the material condition of our lives, calling into question historical accounts of progress. As we shall see, the history of the fens is a history in which the Protestant work ethic is inscribed into the land through the labour of drainage; yet this is an ethic which consumes its own material conditions. Read this way, Weber's Protestant Ethic is a carbon history, and ethnographic studies of the Anthropocene help us to show the entanglements of ideal and material forces towards which Weber's sociology draws our gaze.

As the provocation of the Anthropocene gains momentum, important critiques have been aimed at some of the assumptions inherent in its narrative. Malm and Hornborg (2014) question whether identifying the whole of humankind as a geological agent obscures the unequal patterns of consumption which drive manmade geological changes. In contrast to the treatment of humankind 
as an undifferentiated species, they argue that divisions within the human species are a key part of the story of our impact on 'natural history', while Moore (2015) has argued that the 'easy story' of the Anthropocene should be replaced with the more complex human story of the 'Capitalocene', in which environmental transformation is understood in the context of modernity's strategic relations of power and production. These potent critiques cannot be disregarded: the social sciences cannot and should not simply subsume their analysis into an overarching narrative. Nevertheless, in bringing into focus the geologic force of human activity, I would argue that the key challenge of the Anthropocene to our time perspective remains.

Recent work exploring the Anthropocene has developed the longstanding sociological engagement with temporality (see, for example Adam, 1998) by drawing our attention to what Michael (forthcoming) has described as the proliferation of futures that emerge as we confront our geological agency. Clark (2014) has written about the emergence of new 'geo-politics' emerging in the face of the future of the change of state in earth systems, while Weszkalnys (2014) has written about oil and the 'not yet' of disaster in São Tomé and Príncipe. Here, we see the temporal work of anticipation: the Anthropocene not just as a mark in time, but as a question of what comes next. This resonates with recent explorations of a sociology of the future (Selin, 2008; Adam, 2010); though with the understanding that such futures can only be understood in relation to the historical processes which shape the landforms under our feet and the resources we depend upon.

This paper therefore turns towards geological temporality by offering a study of social life as geological life. I treat the East Anglian fenland as an Anthropocene space - that is, a space in which the characteristics of the Anthropocene epoch are acutely visible - in (at least) two important ways. Firstly, fenland is an anthropogenically transformed land: transformed by mass drainage projects that sought to make the wet-land a dry-land, and transformed by changing social and economic expectations of the nature of the landscape; these transformations can be seen to have had a major social and ecological impact. Secondly, fenland is temporary land. Recognising the interaction between humanity and geology, we are forced to think beyond the short-term time frame of present 
day appearances, and to take account of flux and variability in the relationship between humans, land, and water. To what extent is the experience of a place open to the time-depth required to understand this environmental variation (Irvine, 2014)?

I begin with an account of the anthropogenesis of the present-day landscape. But the creation of this productive land, and the energy devoted to the perpetuation of the landscape as it has come to be shaped, sits uneasily against the long-term history of environmental flux. A focus on economic utility in the present, and the perpetuation of that economic utility, obscures the temporal depth of the landscape; but the material conditions for life in the fens cannot be disentangled from the time-depth of the ground underfoot.

\section{Transformed land}

Human attempts to adapt the fenland landscape through engineering have a long history. Roman drainage and navigation channels had a transformative impact (Rippon, 1999), whilst in the medieval period, monasteries were at the forefront of attempts to embank waterways and dig ditches (Darby, 1940; Sayer, 2009). A systematic programme of drainage was then advanced in the 17th century when a group, led by the Earl of Bedford, obtained contracts from King Charles I to drain the land and make it suitable for agriculture, and to retain property rights in that which they had drained. Such drainage was a major undertaking of venture capitalism; and indeed, the group who undertook the drainage were known as the 'Adventurers'. For these Adventurers, the wetland was deemed waste, to be made productive and therefore profitable through work (for accounts of the drainage of the land see Darby, 1956; Godwin, 1978).

This process of transformation was presented as both a technical and a moral project (Irvine, 2015). Thomas Fuller, giving a favourable opinion of the engineering works taking place in in the mid- $17^{\mathrm{h}}$ century, describes the work in this way: "the river Ouse, formerly lazily loitering in its idle intercourses with other rivers, is now sent the nearest way (through a passage cut by admirable art) to do its errand to the German Ocean" (Fuller, [1655] 1840, p.149). What is striking here is the 
projection of moral values onto the landscape itself: the rivers themselves are lazy and feckless. The land needs not only to be anthropogenically transformed, but also anthropomorphically transformed - reconfigured in its (human-like) moral character. This is by no means an isolated example; throughout William Dugdale's history of the drainage works (commissioned by Lord Edward Gorges, an Adventurer with the Bedford Level Corporation), we are left in no doubt that the predrainage fens were a chaotic space, where the elements themselves are disordered. "What expectation of health can there be to the bodies of men, where there is no element of good? The Air being for the most part cloudy, gross, and full of rotten harrs; the Water putrid and muddy, yea full of loathsome vermin; the Earth spungy and boggy; and the Fire noisome by the stink of smoaky hassocks" (Dugdale, 1662, p.7). The work of drainage is therefore presented as a moral work: the achievement of productivity in the place of waste, order in the place of chaos.

As land is 'improved' in this way, so too are those who dwell there improved. To quote a poem attributed to Samuel Fortrey, and found in another historical narrative of drainage published by Jonas Moore, surveyor for the Adventurers (Moore, 1685):

When with the change of Elements, suddenly

There shall a change of men and Manners be;

Hearts, thick and tough as Hydes, shall feel Remorse,

And Souls of Sedge shall understand Discourse,

New hands shall learn to Work, forget to Steal,

New legs shall go to Church, new knees shall kneel.

Here is Weber's Protestant Ethic at the geomorphological level: drainage improving the moral character of both land and people.

This story of the triumph of technology continued to be proclaimed on $19^{\text {th }}$ century pumping stations, announcing the righteousness of drainage as steam brought ever greater effectiveness to the exclusion of water from land. Perhaps one of the clearest demonstrations of this triumphalism can be read above the entrance to Hundred Foot Pumping Station, Pymoor, near Ely. With the 
installation of a steam powered pumping engine in 1830, the fen poet William Harrison was commissioned to write a poem of celebration:

These Fens have oft-times by water drowned

Science a remedy in water found

The power of steam she said shall be employ'd

And the Destroyer by itself destroyed

Nature is turned against itself. Water is not just pushed out towards the North Sea: it is consigned to the past.

Yet the acceleration of technology which these steam powered pumps represent (and, in turn, represented by the diesel and electrically powered pumps which would replace them in the $20^{\text {th }}$ century) was necessary in order to keep pace with the loss of the peat being drained; and would in turn lead to even greater levels of peat loss. As the land was drained and brought under cultivation, the level of that land rapidly lowered; a consequence of chemical processes of oxidation and breakdown of organic matter following exposure of the formerly waterlogged peat to the air (Godwin 1978, p.126). Peat fen, once drained, wastes away.

By the mid $-19^{\text {th }}$ century the use of steam engines made it possible to drain open bodies of water, such as Whittlesey Mere in Huntingdonshire, completely, creating vast new stretches of farmland. ${ }^{1}$ William Wells, one of the landowners in the area who had driven forward the project of drainage, wrote an account for the Journal of the Royal Agricultural Society of England, describing the scene as the last water was drawn away:

Long before the last pools of water had disappeared from off the bed of the Mere large crowds of people... had assembled... nine out of ten came provided with sacks and baskets to carry off their share of the vast number of fish, which, wherever the eye turned, were floundering in the ever decreasing water... as the fading light of a blood-red sunset fell on the vast multitudes of figures scattered in all directions over the dreary waste of slimy ooze, it left on the mind the same sort of impression of the supernatural as is left by some of Martin's ambitious pictures. (Wells, 1860, pp.138-139)

1 Wells $(1860$, p.147) calculates that 3,000 acres were brought under cultivation by the drainage of Whittlesey Mere. 
The evocation of the painter John Martin is particularly interesting. Martin produced dramatic landscape scenes of heaven, hell, and the last judgement, so the implication is that the transformation calls to mind a vision of the end-times.

For the contemporary ecologist and environmentalist Ian Rotherham, the process of drainage in the east of England constitutes England's greatest ecological disaster. "The consequence of the changes wrought over three centuries probably constitute the greatest single loss of wildlife habitat in Britain and maybe in Europe. This was an ecological catastrophe almost beyond comprehension" (Rotherham, 2013, p.22). He catalogues species now extinct or critically endangered as the wetland that supported them ceased to exist; documenting botanical lists from the $19^{\text {th }}$ and early $20^{\text {th }}$ century, he notes the almost complete loss of many of these plants, and the invertebrates which they supported; while "overall, about 20 per cent of the Cambridgeshire breeding bird fauna present at the beginning of the nineteenth century was lost by the middle of the twentieth" $(2013, \mathrm{p} .89)$. And indeed, the wastage of peat is itself a further environmental disaster, resulting in an enormous release of carbon dioxide into the earth's atmosphere. Rotherham's tone is strident: the process of drainage was the "greatest destruction to nature one could possibly conceive" (2013, p.199), and he writes of the "atrocities" commited by intensive farming (2013, p.9).

Eric Ennion, a naturalist and General Practitioner who lived and worked on the fen edge in Burwell during the first half of the $20^{\text {th }}$ century, narrates the loss of wetland to agriculture by conjuring up an image of the symbolic slaughter of the fen:

\footnotetext{
The water from the ditches and the interlines, the moisture from the peat, bled in an endless trickle into the deep new drain... When all was dry, men set the fen on fire. Spurts of flame began to flicker here and there... Reed beds, sedges and sallows vanished in a whirl of flying ashes amid the crackle and the roar. I went down afterwards. There was a single gull wheeling over the dead black land and a wild duck trying to hide in two inches of water at the bottom of a drain. (Ennion, 1949, p.ix)
}

Here, the drainage channels are seen as agents of destruction, leaving the land barren for everything except arable farming. Yet there are other aspects to their story, to which I now turn my attention. 


\section{Unintended land}

In her recent work exploring the commodity chains of Matsutake mushrooms, the anthropologist Anna Tsing (2015) has drawn attention to the disturbance histories of the lands which produce this highly valued fungus. The forests where matsutake grow are disturbed by grazing goats, and by farmers cutting back branches and raking away the leaves and needles. The cleared, opened up forest, a product of interaction between multiple species, provides the conditions for optimal growth. In describing these disturbance histories, Tsing makes us aware of the importance of unintended consequences within ecologies; the matesuki take advantage and thrive within disturbed landscapes. Returning to the fenland, this is significant in challenging a view of the anthropogenic environment as planned environment. The emphasis upon human sovereignty and capacity to change the (moral) order, as well as the awareness of human habitat destruction, can draw attention away from the unintended consequences of a managed ecology. Ditches are here not only a means of control, but also an unforeseen habitat; not simply the end of a landscape, but a site of possibility.

In my own ethnographic research, conducted since 2011, I have sought different routes to understanding these 'possibilities' of the fenland, working with varied groups who bring different perspectives to the landscape, and have different senses of its past and future: farmers, conservationists, property developments, and others. Here, I wish to illustrate some of the 'unintended consequences' of the drainage described above through two ethnographic encounters: firstly, fieldwork with botanists studying the biodiversity of the fen; and secondly, fieldwork with schoolchildren in fenland schools.

At a November 2014 meeting of the 'Ouse Washes Landscape Partnership' (a network of conservation groups, drainage boards, farmers, and other stakeholders), the term "upside-down hedges" was used repeatedly to describe drainage ditches and to draw attention to their significance for biodiversity. A recent survey of plants and invertebrates within drainage ditches in the area covered by the Landscape Partnership had demonstrated that $48 \%$ of the drains were of 
conservation importance (Graham and Hammond, 2015). As Jonathan Graham, who had carried out the plant surveying for the study, explained at the meeting, "There's a perception that agricultural drains are of limited biodiversity value, but that's simply not to case." Many of the species surveyed were of particular conservation concern. Though some members of the conservation groups at the meeting spoke of farmland as "arable desert", what was being shown was that the drainage ditches supporting these farms were a nationally important manmade habitat.

Notably, there was a correlation between conservation significance and drainage ditch management. Within the fenland, the management of main drains is through the work of Internal Drainage Boards (IDB). Rates are levied on all properties under the jurisdiction of a particular drainage board. Each rate-payer is entitled to vote in elections for board membership, and those who are eligible to be elected to the boards are either owner and occupier of more than 4 hectares, or the occupier (through tenancy) of more than 8 hectares. ${ }^{2}$ These Drainage Boards maintain pumping stations and clear channels to ensure effective drainage of the land in winter; in summer, however, the role of the ditches is reversed; letting water in from high level watercourses in order to allow for spray and sub-irrigation. Given a typical rotation of winter wheat - sugar beet - potatoes, the channels need to be well managed to allow for a constant annual flow; especially given the intensive demand for water generated by spray irrigation of the potato crop. Internal Drainage Boards therefore typically undertake annual weed removal and silt removal on a 5 year basis. The most biodiverse ditches appear to be those with year-round clear open water flow, not too heavily shaded and maintained at an early successional stage (through cutting vegetation back). In other words, the conditions created by management of the ditches for the purpose of intensive arable farming are the very conditions that make the ditches areas of conservation importance.

In July 2015, a group accompanied Jonathan Graham on a fieldtrip to Oxlow drain; a main drainage ditch situated near a dam which splits the system and which serves as a feeder for several smaller drains. The group consisted of an engineer working for the Internal Drainage Board for the

2 The present arrangements are set out in the Land Drainage Act 1991. 
region, representatives from several conservation groups, and others including an angler with an interest in monitoring drainage ditch biodiversity "from a fishing point of view"; I tagged along as an anthropologist. As the IDB engineer explained to us, the ditch is subject to annual maintenance, with the vegetation on the shore cut, and a hydraulic excavator cutting back the plants within the drain right down to bed level; the ditch is also dredged on a 5 year basis. The fields beside the ditch are full of potato plants; it is a hot summer's day, and spray irrigation can be seen all around. As Jonathan explains, at first glimpse this seems like a classic case of "competing interests"; drainage and flood prevention, summer water needs, and biodiversity. Standing on the bank of the ditch, he throws a grappling hook into the water. There's a lot of algae (the channel is nutrient rich given run off from nearby land), and it doesn't look so promising. Yet as he pulls up the hook, we immediately find long stalked pondweed (Potamogeton praelongus); a nationally endangered species. We can see that it's not stressed and in a healthy condition, as it hasn't formed turions ${ }^{3}$ early. Further attempts with the grappling hook find fennel pondweed (Potamogeton pectinatus), hair-like Pondweed (Potamogeton trichoides) and the floating liverwort Riccia fluitans. The ditch was indeed a nationally important habitat; leading the IBD engineer to joke, "oh no, you're not turning this into an SSSI!"

Another perspective on the role of drainage ditches comes from considering their place in children's geographies. This attempt to understand children's perspectives and perceptions has been a major focus of my recent fieldwork in the fens, and so between December 2014 and February 2015, working in collaboration Elsa Lee, an education researcher, I went on numerous walks with groups of children from fenland primary schools ${ }^{5}$, along routes that the children chose and planned out. At one of the schools where we worked, Little Thetford, we were struck by the fact that so many of the children in both of the classes we worked with chose a particular route from the

3 Turions are overwintering buds produced by aquatic plants; one would expect that if the plant was in a stressed condition, turions would have developed already by this stage of the year to anticipate early breakdown of the parent plant.

4 Site of Special Scientific Interest; such a designation would limit the land's agricultural utility.

5 Schools research was with children from Years 3-6 (ages 7-11). 
'Wreck' (as they called the Recreation Ground), to the Thetford Catchwater (a drainage ditch); "it seems like some kind of ancestral route" joked one teacher. In advance of walking the routes with the children, we scouted them out; but try as we might, we could not find a way through. The route simply seemed impossible, so reluctantly we plotted an alternative. When we started the walks, I asked one of the boys who had chosen this route where exactly it was meant to be. "Oh, it's easy. We all go over the ditch, it's fun. You just have to crawl through the trees, then go under a wire, it's not electric or anything, then you get to the ditch and you jump over that."

The idea that the ditches could be places of exploration and play were a regular theme in the children's narratives as they walked through the fens. At Wilburton school, one of the girls, calling my attention to the sound of the water in the ditch, told me she had been here geocaching, while some of the boys spoke of "ditch running" - an adaptation of free running for the fenland environment. " "You run along as fast as you can and jump from edge to edge and try not to fall in." Many of the children clearly thought of ditches as something to jump over: watching one child play in the school hall at Little Thetford, jumping over the lines marking out the sports courts, he told me that he was "jumping over ditches". Many of the children had some awareness of the role of the ditches for drainage; "they keep the land dry, it used to be really soggy"; "when farmers have flooded fields they put ditches in so they don't flood as much"; however, for them they had more significance as places to walk the dog along, or to go fishing, or to play. (While passing by a ditch in Little Thetford, I asked one girl what ditches were for; she answered "it's there so someone can get pushed in"; on another, a girl ran up to me and shouted "Lily fell into a ditch! ... ha, she didn't really, you should have seen your face!’)

As Colin Ward $(1978 ; 1988)$ has described in great detail, in play children adapt the imposed environment for their own purposes, and they are resourceful in finding scope for exploration and excitement in places where adults might fail to see such potential. I offer these

\footnotetext{
6 In their contraction of recreation ground, the children themselves uniformly wrote "Wreck" rather than "Rec" when listing their 'special places'. We have therefore followed their usage here.

7 Libraries and other council buildings in Cambridgeshire often have signs reading "no free running", so in certain contexts this style of interaction with the environment can be a source of tension.
} 
observations of the role of the seemingly unpromising ditch in the everyday lives of children to make a further point about unintended consequences. Ditches may well be rooted in labour, and have the goal of creating productive land, but in the play of children, they become something quite different: sites for exploration and leisure. Once again, rather than being barren, the anthropogenic environment gives rise to new possibilities that may not have been anticipated.

\section{Temporary land}

As we have seen, the transformation of East Anglian fenland has shaped a particular surface level appearance, dominated by the land's utility for arable farming. Yet to understand this as an Anthropocene landscape - that is, to place it within a geological chronology - we also need to see the fenland in time; recognising that the present-day anthropomorphic landscape is but a single point in a much longer story of environmental variation.

When drainage ditches are dug, relics of the past are often made visible; exposed crosssections of extinct riverways, preserved trees and acorns. The unearthed skulls of beavers, extinct in the UK since the $16^{\text {th }}$ century, evoke the former wetland environment of the fens; the 2014 discovery of the skull of a Woolly Rhino by a digger driver in a farm near March creates a phenomenal connection between contemporary agribusiness and megafauna roaming the ice age landscape.

Particularly prominent in the experience of the fens are encounters with the preserved oaks revealed as peat is ploughed and worn away. These "bog oaks" or "black oaks", remains of submerged woodland, are a source of frustration to farmers, as they can wreck machinery, and it takes considerable effort to dig them up: "like pulling teeth," to use the summary of one Huntingdonshire farmer. In March 2012, a giant specimen of Black Oak was found at a farm within the G's Group, a major producer of salad vegetables. The training centre at their headquarters in Barway contains a display about the Oak: 
On first inspection... it was impossible to establish the root or canopy ends; it was then that the penny dropped and we realised that astonishing though this branchless length was, it was actually only a small section of a much, much larger tree... it was so vast its apocalyptic descent would have smashed and crushed everything in its path to then form an airless, silent grave where it lay for thousands of years.

The literature of fenland recollections is rich in speculations about the source of this preserved wood (Irvine and Evans, 2012). Returning to the General Practitioner and naturalist Eric Ennion, past environmental conditions become visible as they protrude from the peat:

Trees from the fringe of the forest still lie under the peat and not long ago a man brought me the lower half of a beaver's skill he had found while digging a ditch... This was certainly not fen country when the forest was at its prime... The tap roots are in the gault - a stiff blue clay - and the trunks lie on top of this, two or three feet deep between it and the surface peat. The North Atlantic tides must have rolled in along the ancient valley of the Rhine and slowly washed the clay away from the surface roots. And then maybe, undermined and already tottering, the forest fell before the onslaught of some wild south-westerly gale. What a crash there must have been! (Ennion 1949, p.45)

The evocation of the ancient Rhine here is significant. Connections with the rivers of continental Europe before the rising sea levels at the end of the last ice age hint at a temporal depth within the landscape, allowing people to think back beyond present-day landforms and coastlines. As the Middle Level Commissioners (an Internal Drainage Board) explain in the history section of an 2013 Information Brochure outlining their work, "In the distant past, Great Britain was part of continental Europe with the rivers of eastern England being tributaries of the River Rhine, which flowed across a flat, marshy plain, which is now the southern North Sea".

The temporal depth of the landscape operates on different registers depending on the context: for example, in conversations with a seed seller from near King's Lynn, the primary attentiveness was to the changes from one agricultural year to the next. The impact of the wastage of the peat and the considerations of changing soil conditions as more fields deep plough the underlying clay, together with changes in market demand, lead to new challenges. For the seed seller, these challenges need to be met with the development of new crop varieties that allow 
farmers to maintain productivity. However, different contexts brings other timescales of variation into view; as the conversation turns to shooting, we discuss places where as a boy he remembers Woodcock (Scolopax rusticola) being shot in great number; now, with the loss of wetland habitat, Woodcock cannot be found as easily in the fens; “I don't shoot woodcock, I don't shoot a great deal actually, but I won't shoot woodcock now because I'm not over over happy about it but in those days it was the thing to try and shoot a right and left woodcock ${ }^{8 \%}$. This led on to conservation about angling, and a mounted fish in his possession, caught by his grandfather in 1902:

Do you know what a Burbot is? It's now believed to be extinct [in the UK]. It's a member of the cod family. It's head is a little bit like a cod, it's got these tendrils? Like a cod does or a Gudgeon. And its got an eel's back so a very long dorsal and pectoral fin... And that was only peculiar to Whittlesey mere, the Nene and the Ouse, I believe... Because the Ouse and the Nene were tributaries of the Rhine when Britain was joined to the continent. I believe, now this is what I've been told by people who are far cleverer than me, that the Burbot was a fish that was peculiar to the Rhine... and therefore a very very ancient fish because it goes back to that period... Very very rare and there has been one I think caught in the late $60 \mathrm{~s}$, but they're believed to be extinct in Britain anyway.

The mounted Burbot (Lota lota) was a relic that linked us not only with the history of Whittlesey Mere and extinctions that may have followed its drainage, but also the more distant past of the glacial maximum and the landbridge, when the Ouse system was linked to the river systems of continental Europe. A very different kind of environment indeed, long before 'fenland' was 'fenland'.

To recapitulate somewhat; I first described the fenland as a site of human transformation. In this section, I have attempted to expand the time-depth of such a description, placing the presentday landscape against a background of long term variation. Yet there is a tension here. While the time-depth of the fenland landscape is encountered in the course of work to transform the fenlands, that act of transformation simultaneously narrows our time horizons by fixing a particular controlled and managed appearance of the landscape as though it were permanent.

8 Killing two woodcock with two consecutive shots from a shotgun. 
Ingold (1993) in his account of the temporality of the landscape describes attentive movement in resonance with ecological and geological rhythms. The human, attending to their own life-process, is necessarily attending to, and contributing to, other life-processes with different temporal spans. For Ingold, the landscape, which he defines as "the world as it is known to those who dwell within" (1993, p.156), and indeed the taskscape ("Just as the landscape is an array of related features so - by analogy - the taskscape is an array of related activities" 1993, p.158), is a "plenum, there are no holes in it" (1993, p.154). Yet in the contemporary fens, there are holes: human activity is dislocated from an understanding of the rhythms upon which it depends, even as evidence of these long term geological processes protrudes into the present. Though an understanding of the long-term history of the relationship between land and water in the fens draws our attention towards flux, the management of the landscape seeks to fix fenland at a particular point in history; even as the effects of peat shrinkage and potential sea level rise increase the vulnerability of the land.

To give an example of this 'fixing' of the landscape: in the Autumn of 2011, the Environment Agency set out proposals for flood defences around Whittlesey Washes, on the banks of the River Nene to the east of the city of Peterborough. These Washes are areas of land left for seasonal flooding, subject to an annual cycle of winter floodwater storage, and summer cattle grazing. The area is an important site for wildfowl, and as such is designated as a Ramsar site ${ }^{9}$ and a Site of Special Scientific Interest.

Following a 2005 inspection, and further investigation of flood capacity in 2007, it was concluded that the banks of the washes - themselves early 19th century earthworks - were no longer sufficient to meet the challenge of potential future floods. In order to avoid the risk of an uncontrolled breach of the banks, a new flood defence scheme was required. The proposals set out involved weakening the flood barrier at a specific point; lowering the top of a $2 \mathrm{~km}$ stretch of the

\footnotetext{
${ }^{9}$ A site designated as of international importance under the UNESCO Ramsar convention on the conservation of wetlands.
} 
south bank by a height of around three quarters of a metre. This would allow for a controlled breach in the event of extreme weather. These proposals met with a great deal of public hostility, building up to a public meeting with the local Member of Parliament (himself a critic of the plans) in January 2012. The perception was that homes, roads, and agricultural land were being placed at risk by a strategy of 'abandonment'.

As a resident opposing the plans made clear: "This has nothing to do with climate change. This has everything to do with priorities. It's a decision not to maintain defences that protect property. So we're being told we're not a priority for spending, okay, then tell us that." As his property was within an area near to the wash, he felt that the resulting uncertainty would have negative an impact on property prices and insurance rates, causing an adverse impact even if no flood came. "There is an option here that'd protect land and protect property but instead they're trying to do it on the cheap." Economic and public policy decisions are here presented as the determining factors that will shape the future landscape.

Washes can be thought of as a space of negotiation, an allowance of land for floodwater storage as a means to protect land upon which people can live and work. Yet what was striking throughout this debate was the sense in which the boundary between land and water had become increasingly fixed and non-negotiable. For those protesting the decision, planning scenarios that allowed water to spread beyond those places where it was currently expected was nothing short of irresponsible.

Indeed, by the summer of 2012, the Environment Agency had changed their decision (a "welcome U-turn" in response to local pressure, as it was presented by the local MP); a $£ 24$ million scheme to reinforce the defences was approved, to be supported with $£ 21$ million from central government (the rest to be paid for by the local authority and drainage boards). The certainties of the present landscape were to be protected by major capital investment in infrastructure. And yet problems with the uncertainty caused by water remain: a recurrent cause of complaint is the effect of floodwater from the washes on a key route from the town, the B1040. As was explained to me at 
the time of the debate above, "you should see the chaos it causes, when that road's out every truck jamming up the roads, if ever there's a flood warning, then that's the whole system jammed up so there's a question could more be done to keep that road open". Here again, flooding is presented as a policy failure. We are reliant on the certainty that particular roads can be used all year around, and the insistence was that more can and should be done to maintain a fixed boundary between the wet and the dry.

This is but one instance of a wider sense of temporal lock-in. As reported in a memorandum submitted by the Central Association of Agricultural Valuers to the UK Select Committee on Agriculture on 15 April 1998:

There is concern that the cost of continual improvement and raising of sea defences may reach a point where the costs incurred could lead to a change of policy. That economic calculation would ignore the social costs that would flow from allowing the sea to make serious inroads in this area: the area of land below sea level runs well into Cambridgeshire - it may not be easy to concede limited areas but not others to the sea without incurring the costs that could have defended the whole. The local population does not anticipate being left to the mercy of the sea.

We therefore see a region historically characterized by flux but now subject to tremendous political and economic pressures to preserve the landscape according to a pattern of a single data-point in time. The effects of environmental variation on the region have become unthinkable. Areas which were once under water are now being farmed; houses sit on land which was once wetland. The present-day economy of the fenland relies on this remaining the case.

The sociologist Barbara Adam (1998) has drawn attention to what she sees as the temporal disjuncture between the present-orientation of economic activity and the temporality of the geologies and ecologies upon which such economic activity rests. She draws attention, for example, to how disconnected intensive agriculture can be from the temporality of the soil that supports it (1998, p.145); indeed, in the context of the fenland we can see peat formed over thousands of years literally waste away as it is brought into service as agricultural land. What is striking here is the 
sense that the temporal awareness of present day economic activity lacks sufficient depth to understand the very environment on which that economic activity depends. The fenland is a process. Such processes are not always visible to us living in the present and relying on resources for immediate needs. Nevertheless they are inherent in the land; inherent, but due to our presentorientation, often out of focus.

\section{"...which once was the floor of the sea"}

Born in Norfolk in 1935, Fred Rooke was a farm worker and a singer who wrote dialect songs reflecting his youth in the county. He was not from the fenlands, yet growing up in East Anglia, the flatness of that landscape still left a lasting impression on him. Recording some of his songs in $1975^{10}$, he explained his inspiration:

Speaking of trains, one thing that really put the wind up me is that ride between Kings Lynn and Cambridge. I see all that flat land what were once underwater and you know I can't for the life of me see what's to prevent that being flooded again. All that water shut back in them dykes, that make me think of power shut in a cage. That make me think of Rhodesian Negroes, or Trade Unions, or the IRA, and if power break loose that ain't no good talking softly to it, and saying "get you back in your cage".

The fens here are presented as a place of political, not simply technological, struggle; a site of capitalism and colonialism, where the power of human economic control seeks to hold back the power of the water. But as the song makes clear, this struggle takes place so against the backdrop of a long-term environmental history - this is land where there once was sea, and that history serves to reminds us of what might be in the future:

There are farmers a-living in the fens which once was the floor of the sea

And it might very well be sea again if the water in the dyke get free

So beware of the hour when the captive power of the water in the dyke get free

There are gangs of men a-hoeing of the peat on the sooty black fields where they grow

10 'Git you hom boy': Fred Rooke's Norfolk Dish, Folktrax 1975. FTX-044. 
But the walls of the dykes stand forty feet above the men who hoe

So beware of the hour when the captive power of the water in the dyke get free

Here, as with Weber's suggestion that the iron cage shall perhaps last until "the last ton of fossilized coal" (1930, p.181) is extracted, economic histories are entangled with the resources upon which they depend, and that which seems certain and all-containing in the present moment cannot be counted upon in perpetuity.

The sociologist Bronislaw Szerszynski (2012) suggests different ways in which the anthropos- in the Anthropocene might be figured. Homo faber, man the maker; Homo consumens, man the consumer; Homo gubernans, man who governs - the "helmsmen" at the wheel of the ship (2012, p.176). Such humanities are certainly visible in Anthropocene East Anglia; a land transformed by human action for the sake of what we wish to consume in the short term, and governed through intensive water management. The work of transformation, consumption, and management can be read as the potent creation of a new resource and new possibilities for life, and it can be read as a process of habitat loss, destruction and extinction. This is the ecological face of Weber's ambivalence towards the social consequences of the work ethic: the 'iron cage' of efficiency and calculation increases productivity, but in doing so it directs land towards the narrow ends of economic utility. But if a focus on the transformative power of humans is necessary for an understanding of the contemporary fenland, it is distorting in that it narrows our time-horizons and places environmental variability out of focus. As Fred Rooke's song makes clear, such claims of human power stand uneasily against the time-depth of an environment that was once sea, and may be again:

And supposing the fenmen all are stood as firmly as can be He'd be gathered up like so much wood and be carried out to sea So beware of the hour when the captive power of the water in the dyke get free

To place humanity in the context of deep time simultaneously humbles and aggrandises it (Irvine 2014, p.168). Even as our actions occupy a negligible time span in relation to the history of the 
planet, our "mechanised petrification" (Weber 1930, p.182) is shown to have had an effect that will be visible in the geological record for the rest of the planet's history - yet this "is itself a memento mori... a reminder of our incipient minerality” (Szerszynski 2012, p.181).

In this paper, I have set out an account of the anthropogenic character of the fenland - its nature as transformed land. This transformation can be read as creation and as destruction; in terms of planned action and in terms of unintended consequences. Yet, in drawing attention to the timedepth of the fenland which is encountered when digging into the land, I have suggested that a shortterm focus on the utility of the anthropogenic landscape serves to obscure the record of flux within what can only be understood as temporary land. There is a temporal disjuncture between the anthropogenesis of the fenland and its long term environmental history. The challenge of the Anthropocene is to see human action as geological action without letting the narrow time horizons

of human resource use distort our understanding of geological time. To see the drainage ditches, and to see the temporal depth of the soils they cut though; and to understand them not as the beginning of a landscape, or as its end, but as a mark in deep time.

\section{Acknowledgements}

I am grateful to the Great Fen Project and the Ouse Washes Landscape Partnership for the opportunity to participate in some of their activities, and also to Little Thetford, Wilburton and Weatheralls Primary Schools for their enthusiastic involvement in the schools element of the research, which was carried out in collaboration with Elsa Lee. My thanks to Libby Peachey, Barbara Bodenhorn, Hildegard Diemberger, Jonathan Woolley and David Sneath for their help and intellectual stimulation throughout this research. 


\section{Funding}

This work has been supported by the AHRC project grant 'Pathways to understanding the changing climate: Time and place in cultural learning about the environment' (AH/K006282/1).

\section{References}

Adam, B. (1998). Timescapes of Modernity: The Environment and Invisible Hazards. London:

Routledge.

Adam, B. (2010). History of the future: Paradoxes and challenges. Rethinking History, 14(3), 361378.

Beck, U. (2010). Remapping social inequalities in an age of climate change: for a cosmopolitan renewal of sociology. Global Networks, 10(2), 165-181.

Chakrabarty, D. (2009). The Climate of History: Four Theses. Critical Inquiry, 35(2), 197-222.

Clark, N. (2014), Geo-politics and the disaster of the Anthropocene. The Sociological Review, 62(S1), 19-37.

Crutzen, Paul J. \& Stoermer, E.F. (2000). The Anthropocene. International Geosphere-Biosphere Programme Global Change Newsletter, 41, 17-18.

Darby, H.C. (1940). The Medieval Fenland. Cambridge: Cambridge University Press.

Darby, H.C. (1956). The Draining of the Fens. Second Edition, Cambridge: Cambridge University Press.

Dugdale, W. (1662). The History of Imbanking and Drayning of Divers Fenns and Marshes. London: Alice Warren.

Ennion, E.A.R. (1949). Adventurers Fen, enlarged edition. London: Herbert Jenkins. 
Evans, C. \& Hodder, I. (2006a). A woodland archaeology: Neolithic sites at Haddenham.

Cambridge: McDonald Institute for Archaeological Research.

Evans, C. \& Hodder, I. (2006b). Marshland communities and cultural landscape from the Bronze Age to the present day. Cambridge: McDonald Institute for Archaeological Research.

Fuller, T. ([1655] 1840). The History of the University of Cambridge from the Conquest to the Year 1634. Cambridge: J. and J.J. Deighton and T. Stevenson.

Godwin, H. (1978). Fenland: its ancient past and uncertain future. Cambridge: Cambridge University Press.

Graham, J. \& Hammond, M. (2015). Investigating ditch biodiversity and management practises in the arable landscape of the Ouse Washes Landscape Partnership Area: a survey of vegetation and aquatic Coleoptera. Littleport, Cambridgeshire: Ouse Washes Landscape Partnership.

Ingold, T. (1993). The temporality of the landscape. World Archaeology, 25(2), 152-174.

Irvine, R.D.G. (2014). Deep time: an anthropological problem. Social Anthropology, 22(2), 157172.

Irvine, R.D.G. (2015). East Anglian Fenland: Water, the Work of Imagination, and the Creation of Value. In K. Hastrup \& F. Hastrup (Eds.), Waterworlds: Anthropology in Fluid Environments (pp. 23-45). Oxford: Berghahn.

Irvine, R.D.G. \& Evans, C. (2012). Greenlands and Waterlands: Digging into Climate History in the East Anglian Fenlands. Current Anthropology, 53(2), 237-239.

Malm, A, \& Hornborg, A. (2014), The Geology of Mankind? A Critique of the Anthropocene Narrative. The Anthropocene Review 1(1), 62-69.

Marsh, G.P. (1864). Man and Nature; or, Physical Geography as Modified by Human Action. New York: Charles Schreibner.

Michael, M. (Forthcoming), Enacting Big Futures, Little Futures: toward an ecology of futures. To 
appear in The Sociological Review

Mitchell, T. (2011). Carbon Democracy: Political Power in the Age of Oil. London: Verso.

Moore, J.W., (2015). Capitalism in the Web of Life: Ecology and the Accumulation of Capital.

London: Verso.

Moore, J. (1685). The History or Narrative of the Great Level of the Fenns, Called Bedford Level. London: Moses Pitt.

Pálsson, G., Szerszynski, B., Sörlin, S., Marks, J., Avril, B., Marks, J., Avril, B., Crumley, C., Hackmann, H., Holm, P., Ingram, J. Kirman, A., Mercedes Pardo Buendía, M.P. \& Weehuizen, R. (2013). Reconceptualizing the 'Anthropos' in the Anthropocene: Integrating the social sciences and humanities in global environmental change research. Environmental Science and Policy, 28, 3-13.

Rippon, S. (1999). Romano-British Reclamation of Coastal Wetlands. In H. Cook \& T. Williamson (Eds.), Water Management in the English Landscape: Field, Marsh and Meadow (pp. 101-21). Edinburgh: Edinburgh University Press.

Rotherham, I.D. (2013). The Lost Fens: England's Greatest Ecological Disaster. Stroud: The History Press.

Sayer, D. (2009). Medieval Waterways and Hydraulic Economics: Monasteries, Towns and the East Anglian Fen. World Archaeology, 41(1), 134-50.

Selin, C. (2008). The Sociology of the Future: Tracing Stories of Technology and Time. Sociology Compass, 2(6), 1878-1895.

Szerszynski, B. (2012). The End of the End of Nature: The Anthropocene and the Fate of the Human. The Oxford Literary Review, 34(2), 165-184.

Tsing, A.L. (2015). The Mushroom at the End of the World: On the Possibility of Life in Capitalist Ruins. Princeton: Princeton University Press.

Ward, C. (1978). The Child in the City. London: The Architectural Press. 
Ward, C. (1988). The Child in the Country. London: Robert Hale.

Weber, M. (1930). The Protestant Ethic and the Spirit of Capitalism, trans. T. Parsons. London: Allen and Unwin.

Wells, W., (1860). The Drainage of Whittlesea Mere. The Journal of the Royal Agricultural Society of England, 21, 134-153.

Weszkalnys, G. (2014). Anticipating oil: the temporal politics of a disaster yet to come. The Sociological Review, 62 (S1), 211-235. 